\title{
A Social Mission is Not Enough: Reflecting the Normative Foundations of Social Entrepreneurship
}

\author{
Ignas Bruder ${ }^{1} \mathbb{D}$
}

Received: 23 August 2019 / Accepted: 11 August 2020 / Published online: 18 August 2020

(c) The Author(s) 2020

\begin{abstract}
Social entrepreneurship is not just an objective description of a phenomenon; it also carries a positive normative connotation. However, the academic discourse barely reflects social entrepreneurship's inherent normativity and often grounds it implicitly on the mission of a social enterprise. In this paper, we argue critically that it is insufficient to ground social entrepreneurship's inherent normativity on a social mission. Instead, we will show how such a mission-centric conception of social entrepreneurship, when put into practice, is prone to enhance rather than diminish societal grievances. In order to give social entrepreneurship an explicit and sound ethical grounding, we draw on integrative economic ethics as a frame of reference. From this perspective, social entrepreneurship necessitates adherence to the discourse-ethically reasoned moral principle in order to live up to its inherent normative validity claim of good entrepreneurship. The consideration of social entrepreneurship practices is crucial to make this approach less vulnerable to ethical critique. The addition of a practice dimension overcomes the mission-centric view of social entrepreneurship and opens up a typology of enterprise forms, thereby enabling a more fine-grained distinction between social enterprises and other forms of organization.
\end{abstract}

Keywords Normative critique of social entrepreneurship $\cdot$ Integrative economic ethics $\cdot$ Critique of economism $\cdot$ Social enterprise $\cdot$ Normativity $\cdot$ Discourse ethics $\cdot$ Typology

\section{Introduction}

Even though social entrepreneurship research is viewed as pre-paradigmatic (Lehner and Kansikas 2013; Nicholls 2010), the notion of social entrepreneurship, as opposed to 'regular' business entrepreneurship, is rather uncontested and currently referred to mainly as good entrepreneurship (Dey and Steyaert 2012), which implies ethical soundness and a positive impact on society. From a critical social science perspective, this positive connotation shared by large parts of the social entrepreneurship discourse (Dacin et al. 2010) is not surprising. Theorizing and reasoning efforts, as well as the general labeling of phenomena as something in social sciences are not value-free endeavors but imply making normative validity claims and are thus unavoidably normative (Habermas 1988b; Apel 1998; Myrdal 2013; Putnam 2002; Rudner 1953; Douglas 2000; Longino 2008). The

Ignas Bruder

ignas.bruder@fu-berlin.de

1 Department of Management, Freie Universität Berlin, Garystr. 21, 14195 Berlin, Germany same goes, of course, for conceptions of social entrepreneurship containing the validity claim that it is right to attribute the prefix 'social' to the specific conception being proposed. The prefix 'social' itself is not a value-free description, either, but is perceived by people positively (Andersson and Self 2015) and holds the normative validity claim of good entrepreneurship - as being beneficial for society and ethically legitimate.

Against this background, any conception of social entrepreneurship necessarily touches upon a normative discourse about what criteria good entrepreneurship should fulfill. Put differently, it is a discourse about the adequate grounding of social entrepreneurship's inherent normative validity claim of being good entrepreneurship. The outcome of such a discourse should be a conception of social entrepreneurship that scholars find normatively sound and beneficial for society. However, it is an open question whether the social entrepreneurship conceptions proposed in the scientific discourse can live up to the inherent normative validity claim carried by the term 'social'. A critical examination of the normative foundations of social entrepreneurship is crucial to prevent this concept from becoming hollowed out. The ethical 
legitimacy of social entrepreneurship could be questioned if research and practice continuously celebrate entrepreneurial conduct as 'social' despite the fact that it might encompass harmful actions and outcomes. Therefore, it is the aim of this paper to examine the normative foundations of social entrepreneurship critically, and to give social entrepreneurship an explicit and sound ethical grounding.

Even though social entrepreneurship's inherent normativity is unavoidable, the social entrepreneurship discourse barely touches explicitly upon its normative dimension. In many cases, this question is handled implicitly by concentrating the normatively demanding part of the term, namely 'social', on social entrepreneurship's mission alone (e.g., Dees 2001; Mair and Martí 2006; Austin et al. 2006; Zahra et al. 2009; Alvord et al. 2004; Martin and Osberg 2007; Short et al. 2009). Such conceptions thus implicitly assume that a social mission is sufficient grounding for social entrepreneurship's inherent normative validity claim. In this paper, we focus our analysis on such mission-centric conceptions of social entrepreneurship, which are prominently featured in the scientific discourse, as will be shown.

We conduct the critical examination from the perspective of 'integrative economic ethics' (henceforth: integrative ethics), which is a discourse-ethical approach based on the elaboration and justification of the moral point of view (Ulrich 2008a). This approach stands out, in that it undertakes no "abandonment of reflection in the face of empirically given circumstances" (Ulrich 2008a, p. 84) and integrates all conditions of business activity and systematic economic interrelations into ethical reflection instead of taking them for granted. Operating with such resoluteness, integrative ethics has already proven insightful regarding the uncovering and critical examination of the normativity inherent in theories and concepts from the field of economics (e.g., Thielemann 2000, 2010b) as well as in the area of management (e.g., Thielemann and Ulrich 2009; Ulrich and Thielemann 1993). Against this background, integrative ethics appears as a promising approach to provide what Greenwood and Freeman (2018) regard as a benchmark for highly meaningful business ethics: deep ethical analysis through problematization.

This paper contributes to social entrepreneurship studies by clarifying the ethical deficiencies of the widespread mission-centric view on social entrepreneurship. We show how such conceptions (i) ignore the perfect duties (Kant 1785/2012; Hill 1971) of social entrepreneurs and (ii) how some of these conceptions import the ethically misleading nature of economism into social entrepreneurship studies, which implies that perfect duties and imperfect duties are ignored. Thereby, we contribute to the normative critique of social entrepreneurship (Dey and Steyaert 2012). Furthermore, by drawing from the approach of integrative ethics, we shift the focus from the mission to social entrepreneurship practices, which are the mundane, recurring doings and sayings (Schatzki 2002) of organizational members. We argue that the locus of the moral principle cannot be limited to a mission because practices matter ethically, especially with regard to an enterprise's perfect duties. Thereby, we contribute to an ethically sounder conception of social entrepreneurship and ground it on an explicit ethical frame of reference (Slottke 2013). Finally, by overcoming missioncentricity and viewing practices and mission as constitutive features of social entrepreneurship, we contribute to a more fine-grained distinction of social enterprises from other enterprise forms such as pseudo-social enterprises.

\section{Mission-Centricity: A Point of Convergence Among the Plethora of Social Entrepreneurship Conceptions}

Social entrepreneurship is not merely an objective description of a phenomenon; like all conceptions of 'entrepreneurship' or 'corporation' it is of an inherently normative nature because of the normativity inherent in any reasoning and choice of terminology in the social sciences (Thielemann 2010b; Habermas 1988b; Apel 1998; Myrdal 2013; Putnam 2002; Rudner 1953; Douglas 2000; Longino 2008). Peter Ulrich (2008a, p. 377) underscores this with regard to conceptions of corporation: "Whether we reflect upon it or not, we inevitably have a certain normative 'social theory' at the back of our minds, i.e. a comprehensive economic and socio-philosophical understanding of a corporation's position in society and of the corresponding economic order." Thus, when critically examining the social entrepreneurship discourse, the task lies in uncovering the underlying normativity of social entrepreneurship conceptions, thus making them accessible to ethical reflection.

The term social entrepreneurship is special in this regard because conceptions of social entrepreneurship have to deal with the normative aspiration inherent in the prefix 'social'. Due to the distinction from 'regular' business entrepreneurship, the prefix 'social' carries the normative validity claim that social entrepreneurship is particularly legitimate and beneficial for society. This inherent normativity is hardly avoidable, even if we are only interested in a distanced description of the empirical world. By proclaiming 'Organization $A$ is an instance of social entrepreneurship and organization B is not', we already simultaneously voice the normative validity claim that it is right to award organization A the attribute 'social', while organization B does not deserve it. Thus, with regard to every conception of social entrepreneurship one may legitimately ask: How do you ground the normative validity claim of being 'social'?

Despite the myriads of social entrepreneurship conceptions (Dacin et al. 2010; Conway Dato-on and Kalakay 
2016), we can identify an underlying common denominator that many approaches seem to share regarding the 'social' element of social entrepreneurship. Most approaches anchor their understanding of social entrepreneurship on a social mission. Whether it is a not-for-profit organization trying to gain extra funds (e.g., Lasprogata and Cotten 2003) or an entrepreneur realizing a social innovation (e.g., Pryor et al. 2016), the social mission remains the nucleus. Commonly, an organization is created or entrepreneurial business activity is involved in order to pursue that social mission. Some rather wide conceptions of social entrepreneurship even stay on this rather abstract level (e.g., Thompson and Doherty 2006; Cochran 2007; Barendsen and Gardner 2004).

Building on this consensus that a social mission is a vital part of social entrepreneurship, some scholars seem to conclude that social entrepreneurship's inherent normativity is also sufficiently grounded on a social mission (e.g., Dees 2001). This is convenient because by relating to a social mission one can tick off, as it seems, the complicated normative questions related to the social dimension of social entrepreneurship. Whenever the social dimension of social entrepreneurship is limited solely to its mission, we call such conceptions of social entrepreneurship mission-centric. We are aware that the term 'mission-centric' is borrowed from Alter (2008), who uses it to differentiate between social enterprise business models. We use the term to delimit social entrepreneurship conceptions: those that see social entrepreneurship's social dimension entirely covered by its mission and others that relate social entrepreneurship's social dimension to several aspects.

Mission-centric conceptions of social entrepreneurship do not necessarily speak of a social mission literally, even though some of them do (e.g., Lasprogata and Cotten 2003; Hockerts 2006). The mission of an organization refers to its goals and its raison d'être (Drucker 1973; Ebrahim et al. 2014). Thus, a social mission implies that the raison d'être of an organization - the reason for its existence-and its goals have to qualify as being social. Of course, these features can be expressed in other terms, without literally speaking of a mission. Hervieux and Voltan (2018) criticize the fact that the social problems addressed are only rarely researched in social entrepreneurship studies. This might be because conceptions of social entrepreneurship often state that the mission needs to be social, but do not spell out exactly what a social mission is.

As depicted in Table 1, there are three different approaches among mission-centric conceptions of social entrepreneurship with only marginal differences. One approach puts its focus explicitly on the goal dimension of a mission. Following that approach, social entrepreneurship is social because it pursues social objectives or social aims (Short et al. 2009; Shaw 2004; Hibbert et al. 2005). Among the three approaches, this one is the most general, since social goals can encompass many things. A second approach, with a larger followership, conceives social entrepreneurship as addressing or solving social problems (Mair and Martí 2006; Alvord et al. 2004; Seelos and Mair 2005; Martin and Osberg 2007; Barendsen and Gardner 2004; Thompson and Doherty 2006; Cochran 2007; Light 2006). Addressing or solving social problems also falls into the mission category, since overcoming a particular social problem is a goal and can even be the raison d'être of such enterprises or entrepreneurs. These approaches are picked up by many scholars, with some conceptions being cited more than 2000 times. The third approach conceives social entrepreneurship as contributing to an increase in social value or social wealth (Dees 2001; Zahra et al. 2009; Austin et al. 2006; Nicholls 2008; Perrini and Vurro 2006; Peredo and Mclean 2006; Certo and Miller 2008; Chell 2008; Sharir and Lerner 2006). This approach bases the social dimension of social entrepreneurship on a particular outcome, that of social value or social wealth, which is also rather general. Since this outcome relates to the goals of a social enterprise or social entrepreneur, it is one way of constituting a social mission. This type of mission-centric social entrepreneurship is well received as well, with some conceptions being cited over 4000 times.

The three different approaches within the mission-centric view on social entrepreneurship are very consistent and differ only in nuances. Addressing social problems is one specific way of following social aims. Following social aims as well as addressing social problems both contribute to the increase of social value. These approaches only focus on different aspects of social missions at different levels of abstraction, but are perfectly in line with one another. As indicated by the citation counts in Table 1, the missioncentric view is well received. It is also shared by some key figures that have helped to develop the academic field (e.g., Dees 2001) and spreads across different research streams on social entrepreneurship (e.g., Lasprogata and Cotten 2003; Tracey and Jarvis 2007; Austin et al. 2006; Alvord et al. 2004).

In general, the concept of a social mission seems convincing, as without it the distinction between entrepreneurship and social entrepreneurship, as well as between regular businesses and social enterprises, would be very difficult, if not impossible to make. Thus, a social mission is a necessary condition for social entrepreneurship. However, this does not guarantee that it is also a sufficient condition. In contrast to the widespread mission-centric view, there are conceptions of social entrepreneurship that do not limit its social dimension to a social mission alone. Defourny and Nyssens (2012), for instance, stress that social entrepreneurship implies a limited profit distribution to avoid profitmaximizing behaviors and has a participatory nature, involving different parties affected by its activity. Furthermore, 
Table 1 Overview of mission-centric social entrepreneurship/social entrepreneur conceptions (adapted from Dacin et al. (2010) and Conway Dato-on/Kalakay (2016))

Source

Conception of social entrepreneurship or social entrepreneur

Citations

(Google

Scholar)

Conceptions featuring social goals

Hibbert et al. (2005, p. 159)

Social entrepreneurship can be loosely defined as the use of entrepreneurial behaviour for social ends rather than for profit objectives, or alternatively, that the profits generated are used for the benefit of a specific disadvantaged group

Shaw (2004, p. 195)

The work of community, voluntary and public organizations as well as private firms working for social rather than only profit objectives

Short et al. (2009, pp. 171-172)

The distinctiveness of social entrepreneurship lies in using practices and processes that are unique to entrepreneurship to achieve aims that are distinctly social, regardless of the presence or absence of a profit motive

Conceptions featuring solutions of social problems

Alvord et al. (2004, p. 262)

Social entrepreneurship creates innovative solutions to immediate social problems and mobilizes the ideas, capacities, resources, and social arrangements required for sustainable social transformations

Barendsen and Gardner (2004, p. 43)

Cochran (2007, p. 451)

Individuals who adopt entrepreneurial strategies to tackle social issues

Social entrepreneurship is the process of applying the principles of business and entrepreneurship to social problems

Light (2006, p. 50)

A social entrepreneur is an individual, group, network, organization, or alliance of organizations that seeks sustainable, large-scale change through pattern-breaking ideas in what or how governments, nonprofits, and businesses do to address significant social problems

Mair and Martí (2006, p. 37)

Martin and Osberg (2007, p. 35)

A process involving the innovative use and combination of resources to pursue opportunities to catalyze social change and/or address social needs

We define social entrepreneurship as having the following three components: (1) identifying a stable but inherently unjust equilibrium that causes the exclusion, marginalization, or suffering of a segment of humanity that lacks the financial means or political clout to achieve any transformative benefit on its own; (2) identifying an opportunity in this unjust equilibrium, developing a social value proposition, and bringing to bear inspiration, creativity, direct action, courage, and fortitude, thereby challenging the stable state's hegemony; and (3) forging a new, stable equilibrium that releases trapped potential or alleviates the suffering of the targeted group, and through imitation and the creation of a stable ecosystem around the new equilibrium ensuring a better future for the targeted group and even society at large

Seelos and Mair (2005, p. 241)

Social entrepreneurship creates new models for the provision of products and services that cater directly to basic human needs that remain unsatisfied by current economic or social institutions

Thompson and Doherty (2006, p. 362)

Conceptions featuring creation of social value Austin et al. (2006, p. 2)

Certo and Miller (2008, p. 268)

Social enterprises_-defined simply—are organisations seeking business solutions to social problems

Social entrepreneurship is an innovative, social value-creating activity that can 4049 occur within or across the non-profit, businesses or government sectors

Social entrepreneurship refers to the identification, evaluation, and exploitation of opportunities that result in social value

Process by which 'entrepreneurs (both social and economic) consciously garner alienable resources (e.g. through networking and other processes) and use their personal or human capital in order to achieve their espoused mission of wealth and social value creation'

Dees (2001, p. 2)

Social entrepreneurship is the process of pursuing innovative solutions to social problems. More specifically, social entrepreneurs adopt a mission to create and sustain social value. They draw upon appropriate thinking in both the business and nonprofit worlds and operate in a variety of organizations: large and small; new and old; religious and secular; nonprofit, for-profit, and hybrid 
Table 1 (continued)

\begin{tabular}{|c|c|c|}
\hline Source & Conception of social entrepreneurship or social entrepreneur & $\begin{array}{l}\text { Citations } \\
\text { (Google } \\
\text { Scholar) }\end{array}$ \\
\hline Fowler (2000, p. 638) & $\begin{array}{l}\text { Social entrepreneurship is the creation of viable socio-economic structures, } \\
\text { relations, institutions, organizations and practices that yield and sustain } \\
\text { social benefits }\end{array}$ & 704 \\
\hline Nicholls (2008, p. 23) & $\begin{array}{l}\text { Innovative and effective activities that focus strategically on resolving social } \\
\text { market failures and creating new opportunities to add social value systemi- } \\
\text { cally by using a range of resources and organizational formats to maximize } \\
\text { social impact and bring about change }\end{array}$ & / \\
\hline Peredo and Mclean (2006, p. 64) & $\begin{array}{l}\text { Social entrepreneurship is exercised where some person or persons aim either } \\
\text { exclusively or in some prominent way to create social value of some kind, } \\
\text { and pursue that goal through some combination of (1) recognising [sic] and } \\
\text { exploiting opportunities to create this value, (2) employing innovation, (3) } \\
\text { tolerating risk and (4) brushing aside limitations in available resources }\end{array}$ & 2174 \\
\hline Perrini and Vurro (2006, p. 60) & $\begin{array}{l}\text { We define SE as a dynamic process created and managed by an individual } \\
\text { or team (the innovative social entrepreneur), which strives to exploit social } \\
\text { innovation with an entrepreneurial mindset and a strong need for achieve- } \\
\text { ment, in order to create new social value in the market and community at } \\
\text { large }\end{array}$ & 334 \\
\hline Sharir and Lerner (2006, p. 7) & $\begin{array}{l}\text { The social entrepreneur is acting as a change agent to create and sustain social } \\
\text { value without being limited to resources currently in hand }\end{array}$ & 824 \\
\hline Zahra et al. (2009, p. 522) & $\begin{array}{l}\text { Social entrepreneurship encompasses the activities and processes undertaken } \\
\text { to discover, define, and exploit opportunities in order to enhance social } \\
\text { wealth by creating new ventures or managing existing organizations in an } \\
\text { innovative manner }\end{array}$ & 2383 \\
\hline
\end{tabular}

Thompson (2002, p. 413) regards social entrepreneurs as "concerned with caring and helping", which describes more of a general attitude than a type of mission. In his conception of the related concept of social business, Yunus (2010) does not settle on a social mission, but stresses other criteria as well, such as good working conditions, gender equality or a general neglect of profit maximization. The aspects mentioned in these few alternative approaches refer to how an organization or an entrepreneur operates rather than to what the mission pursued is. Whereas these approaches have a wider horizon than the mission-centric ones, their ethical grounding of the normative validity claim behind the prefix social remains implicit as well.

In conclusion, the mission-centric view on social entrepreneurship is not a fringe phenomenon but prominently represented in the academic field of social entrepreneurship studies, and popularly cited among scholars. We need to acknowledge that mission-centric approaches seldom explicitly limit the social dimension of social entrepreneurship to the mission dimension. Instead, mission-centricity is often implicit. Whatever the motives or elaborations leading to mission-centric conceptions of social entrepreneurship might be, the implicit conclusion is always that the social dimension, with its inherent normativity, is sufficiently grounded within the realm of social entrepreneurship's mission and its accomplishment. In the following section of the paper, we briefly outline the ethical frame of reference that guides our further analysis, before critically examining in the subsequent section whether a social mission is sufficient grounding for social entrepreneurship's inherent normativity. Because, in our understanding, any critical examination requires that a perspective is taken, we regard it as important to be transparent in this regard.

\section{Integrative Economic Ethics: A Radically Different Business Ethics, Taking a Critical Perspective}

If one argues from a critical social science paradigm, which rejects the possibility of value-free social science and views it as implicitly normative (Habermas 1988b; Apel 1998; Myrdal 2013; Putnam 2002; Rudner 1953; Douglas 2000; Longino 2008), this naturally has implications for business ethics. Such a paradigm sharpens the eye for the (implicit) normative underpinnings of approaches to economic and business theories in general and business ethics in particular. Following this critical paradigm, integrative ethics is in sharp contrast to approaches advocating a separation thesis (Freeman 1994; Wicks 1996), which posits that the worlds of business and ethics are separate, thereby viewing economic and business activity as well as theories of them as unquestionably value-free and taken-for-granted conditions of ethical reflection. In line with Freeman's (1994) and 
Wicks' (1996) criticism of the separation thesis, the ambition of integrative ethics is to overcome this separation by integrating ethical reflection into business theorizing.

The separation thesis limits the scope of possible ethical insights with regard to business. By declaring business as separate from ethics, the separation thesis sweepingly legitimizes all business activity and business theory, since anything that is value-free and separate from ethics cannot be ethically misguided (Thielemann 2000). Thus, business ethics that conforms to the separation thesis always contains a halt in ethical reflection (Ulrich 2008a). Some approaches to business ethics make a halt in ethical reflection before the assumptions of economic and business theories, e.g., advocating that responsible business action is equivalent to profit making (Friedman 1970) or approaches arguing that the meaningfulness of responsible business action depends on the business case for it (e.g., Salzmann et al. 2005). Other approaches, often found in the CSR field, acknowledge the need for genuinely responsible business action but advocate that ethics needs to be applied to business in a corrective manner, thereby making a halt in ethical reflection before the empirical circumstances in which businesses find themselves (Kinderman 2012).

Both halts in ethical reflection are problematic for the endeavor of developing an ethical grounding for social entrepreneurship. Since some critique of social entrepreneurship also addresses its business side (Dey and Steyaert 2012; Garrow and Hasenfeld 2014; Eikenberry and Kluver 2004), business ethics that seeks to provide an ethical grounding for social entrepreneurship that is less vulnerable to critique cannot exclude assumptions of economic and business theory from ethical reflection. Furthermore, excluding the empirical conditions of business activity from ethical reflection would leave an immense blind spot, because social entrepreneurship is geared towards changing those very conditions in which businesses and societal actors operate (Dey et al. 2016). Hence, in order to develop a grounding of social entrepreneurship, integrative ethics seems a valid alternative that entirely overcomes the separation thesis and makes no halt in ethical reflection.

\section{Kantian and Discourse-Ethical Foundation}

Integrative ethics is a deontological ethics informed by discourse ethics and conceived in adherence to the discourseethically grounded moral principle, understood as the principle of universalization (Apel 1987; Habermas 1990). Since discourse ethics builds on the categorical imperative, it can be regarded as a Kantian ethics (Habermas 1988a). Thus, integrative ethics also belongs to the Kantian spectrum. Discourse ethics extends Kant's argumentation, because it is able to provide a grounding of the categorical imperative (Kant 1785/2012) on the reciprocal recognition of interactants in discourses (Ulrich 2008a; Apel 1987). In doing so, discourse ethics does not run into an infinite regress, because it grounds the categorical imperative on the pragmatic preconditions of argumentation that nobody can reasonably argue against. ${ }^{1}$ Since discourse ethics does not contradict any central Kantian points but only clarifies some of them, integrative ethics draws from Kantian as well as from discourse-ethical arguments.

Besides the discourse-ethical grounding of the moral principle, integrative ethics follows the Kantian distinction between perfect and imperfect duties (Kant 1785/2012; Thielemann 1996). Kant identifies a perfect duty by the criterion that an act breaching a perfect duty cannot be universalized without contradiction (Kant 1785/2012; Ohreen and Petry 2012). Imperfect duties differ from perfect duties, because an act breaching an imperfect duty can, in principle, be universalized without contradiction, yet such a universalization is nothing that one can reasonably will (Kant 1785/2012). Consequently, perfect duties are narrow duties describing principles that are definite and thus always apply (Hill 1971). An example of a perfect duty is the prescription to always regard the dignity of others (Robinson 2019), e.g., one's employees, which leaves no latitude regarding the occasions on which to fulfill this duty. This duty should be fulfilled at all times and towards all people. Imperfect duties, on the other hand, are indefinite principles that indicate "some general end to be promoted" and leave

\footnotetext{
${ }^{1}$ For readers not familiar with the reasoning behind discourse ethics, we provide a short outline of how the moral principle is grounded in discourse ethics. The discourse-ethical grounding of the moral principle unfolds in the shape of a fictional discourse with an ethicsskeptic. Let us assume a skeptic argues against the categorical imperative's proscription to objectify humans, which is one formulation of the moral principle. While doing so, that skeptic voices the validity claim 'The categorical imperative's proscription to objectify humans does not count for me'. But voicing a validity claim is only possible when following the pragmatic logic of argumentation. Hence, by voicing this validity claim, that skeptic has already implicitly recognized the addressees of his validity claim as individuals, approachable through arguments and therefore as humans of equal dignity. Thus, that skeptic commits a pragmatic self-contradiction when trying to argue against the moral principle, because the moral principle is grounded in the very nature of argumentation (Ulrich 2008a). More generally, when trying to put forward a convincing argument, we also already presume the moral principle as the principle of universalization (Thielemann 2010a). While developing a convincing argument, we try to think of possible counterarguments that our addressees, and even unknown opponents could legitimately raise and try to counter those counterarguments in foro interno. Since an argument is most convincing when nobody can legitimately raise a concern against it, which is the very meaning of validity, we try to find as universal arguments as possible. Thereby, we already presume the principle of universalization within the mode of discursive arguing and therefore cannot reasonably argue against it. However, if we cannot reasonably argue against something, we can view it as a "rationally irreducible normative basis" (Ulrich 2008a, p. 65).
} 
considerable latitude for discretion regarding their realization (Hill 1971, p. 58). Thus, imperfect duties prescribe that one has to promote an end or avoid something "sometimes, to some extent", as long as one does not reject the principle of the imperfect duty as a whole (Hill 1971, p. 56). Integrative ethics discusses the duty of solidarity, for instance, as being an imperfect duty (Thielemann 1996), which leaves as much latitude as the imperfect duty of beneficence. For example, according to the imperfect duty of beneficence, one has the duty of being charitable towards others, but one can decide freely when one does so and towards whom (Hill 1971). It is not morally illegitimate to refrain from an action that would be charitable to somebody in a particular situation, as long as one does so from time to time and does not reject the imperfect duty of beneficence entirely. Building on this distinction and on discourse-ethical reasoning, integrative ethics reflects and critically examines the normative underpinnings of economic and business theory.

\section{A Business Ethics Built on the Critique of Economism}

The ethical critique of economism is a central pillar of integrative ethics. We speak of economism whenever economic rationality, understood as following the principle of selfinterest maximization, is superelevated and postulated as the guiding principle of human conduct (Ulrich 2008a; Ulrich and Thielemann 1993). From this perspective, economic rationality is not a value-free conception but a normative one, since every conception of rationality determines how agents should act if they want to claim the normative label 'rational' (Ulrich 2008a). According to economism, agents are only seen as being 'rational' when they consequently stick to the maximization of self-interest. If a self-interest maximizing agent is confronted with claims stemming from stakeholders of his actions, by definition he ignores all stakeholder claims that will have no possible effect on the furthering of his self-interest. The content and possible legitimacy of these claims are completely irrelevant in economism, as long as these claims are no threat or opportunity to an agent's maximization deliberations. Thus, in economism stakeholders only become relevant if they are instrumental for or a constraint to self-interest maximization.

However, if an agent is only interested in the instrumental properties of others, as in the case of a pure self-interest maximization, we can say with Kant that s/he stops viewing other human beings "as an end" of his or her actions and treats them "merely as a means" (Kant 1785/2012, p. 29)—a means of his or her self-interest maximization, to be precise (Thielemann 2010a, 2000). Thus, economism implies an objectification of individuals, which is a violation of the moral principle (Thielemann 2010a). Economism's main principle of self-interest maximization is not universalizable, since one cannot argue for the objectification of others (that logically follows from self-interest maximization) without committing a pragmatic self-contradiction (Apel 1998; Ulrich 2008a). Because self-interest maximizing agents only react to opportunities or threats regarding their self-interest and to nothing else, economism culminates in the antithesis of rationality in the philosophical sense as being approachable through moral arguments. With the normative attribution of rationality, economistic approaches try to establish the right of actors to maximize their self-interest, yet without distributing any moral obligations to actors. Thus, economism can be regarded as an ethics without morals (Thielemann and Wettstein 2008). Economism implies an ethics of the law of the jungle, because the power to thwart an agent's maximization deliberations alone decides whose claims should be considered and whose can be marginalized (Thielemann 2010a). Some even argue that economism meets the criteria of an ideology that needs to be overcome (Huehn 2008). Hence, integrative ethics rejects both economic rationality as a conception of rationality and economism as an ethics (Ulrich 2008a).

The consequence of integrative ethics' critique on economism is not to condemn all self-interest seeking as ethically illegitimate. It only means that the superelevation of selfinterest to the highest principle of human conduct via its maximization is not ethically justifiable. Yet, since this is exactly what happens in economism, it is not a sound ethical conception. Seeking self-interest and thereby using one's market power has far less potential to be problematic if it is done within reason, embedded into values (Selznick 1992) and categorically subordinated to the normative precondition of legitimacy (Ulrich 2008a). This means that claims from all stakeholders are scrutinized for (ethical) legitimacy and the legitimate stakeholder claims are foremost considered in an enterprise's actions, even before profit interests. Since putting legitimate stakeholder interests before profits is not always feasible for enterprises operating in competitive markets, integrative ethics argues for a regulatory ethics to make sure that those citizens and enterprises who want to act responsibly are not hindered to do so by competitive pressures (Ulrich 2008a; Thielemann 2010a).

\section{Ethical Shortcomings of Mission-Centricity in Social Entrepreneurship: From Blanked Out Duties to Economistic Confusions and Utilitarian Tendencies}

In mission-centric social entrepreneurship, social entrepreneurship's normative validity claim of being good entrepreneurship is grounded solely and exclusively on a social mission and seldom engaged with explicitly. In this section, we carve out the ethical shortcomings of mission-centric social entrepreneurship. First, we discuss how all mission-centric 
conceptions ignore the perfect duties of social entrepreneurs. Second, we show how some mission-centric conceptions, namely those explicitly incorporating the maximization principle, import economistic confusions into social entrepreneurship. Third, we uncover how the mission-centric approaches maximizing social impact show utilitarian tendencies, and present a critique thereof.

The mission-centric view on social entrepreneurship posits only the criterion that a mission needs to qualify as being social in order to ground social entrepreneurship's inherent normativity. At first, we need to reflect the ethical implications of this criterion. In general, following a mission that can be legitimately labeled as 'social' is not a bad thing. It implies that, at some point, a social entrepreneur has identified a societal grievance or some kind of disadvantage that $\mathrm{s} / \mathrm{he}$ has decided to address by founding a social enterprise. We argue that the ends pursued in social missions fall into the category of imperfect duties. As listed in Table 1, social missions, be they related to social goals, alleviating social problems or creating social value, relate to the aim of being charitable towards others, which stems from the imperfect duty of beneficence. The duty of beneficence is among the imperfect duties that leave the most latitude of discretion (Hill 1971). Thus, a social mission is a manifestation of a social entrepreneur's choice as to when and to what extent $\mathrm{s} / \mathrm{he}$ wishes to promote the end of beneficence.

In any case, social entrepreneurs promote meritorious ends following the imperfect duty of beneficence through founding an enterprise that addresses a social mission. If the criterion that a mission needs to qualify as being social contained ends, the promotion of which was a perfect duty, all entrepreneurial activity not pursuing social missions would be ethically illegitimate. Yet, we do not see the grounds to dispute enterprises their ethical legitimacy only because they are not social enterprises. Rather, we argue that a social mission is an expression of a social entrepreneur acting upon the imperfect duty of beneficence, while other entrepreneurs can legitimately decide to fulfill their imperfect duties of beneficence outside the entrepreneurial realm, e.g., through charity or social activism (Thielemann and Ulrich 2009). Thus, grounding social entrepreneurship's inherent normativity on a social mission implies granting the normatively charged label 'social' to an enterprise under the condition that this enterprise's mission follows ends that concur with a social entrepreneur's imperfect duty of beneficence.

We argue that mission-centric social entrepreneurship's focus on imperfect duties is reasonable, but not sufficient to warrant a legitimate grounding of social entrepreneurship's inherent normativity. As a mission clarifies the raison d'être and goals of an organization (Ebrahim et al. 2014; Drucker 1973), it leaves the means with which the goals are to be achieved and the activities that derive from the raison d'être entirely unspecified. Thus, there is no more ethical guidance to be gained from a social mission other than that it is the manifestation of a social entrepreneur acting upon the imperfect duty of beneficence. The missioncentric perspective stays entirely silent regarding perfect duties, which are duties that leave no latitude and always need to be considered. However, providing a grounding for any conception with the ambition of ethical soundness while ignoring the most basic, perfect duties, appears miscarried. For it makes a difference ethically whether a social mission derived from the imperfect duty of beneficence is pursued in a way that, for example, the dignity of an enterprise's employees is preserved or not. For instance, the social mission of providing clean drinking water to areas affected by drought (an aim perfectly in line with the imperfect duty of beneficence) can be pursued by an enterprise that is running its water bottling in sweat shops under slave-like conditions. Such an enterprise would not live up to the normative validity claim inherent in the term 'social', because it breaches the perfect duty to regard the dignity of one's employees. However, in mission-centric social entrepreneurship, such an enterprise would be attributed the normatively charged label 'social' solely on the basis of a social mission, because perfect duties in pursuing the 'social' goal are simply not considered in this conception. The fact that perfect duties in the mission-centric conception of social entrepreneurship are being ignored may not be deliberate. Maybe in some cases, authors even implicitly assume that social entrepreneurs fulfill their perfect duties by default and therefore do not discuss these explicitly. However, blanking out perfect duties from the conception of social entrepreneurship leaves the door open for economistic confusions that have significant ethical shortcomings and spread into social entrepreneurship studies.

\section{Economistic Confusions}

Among the mission-centric approaches there are a number conceiving social enterprises as maximization endeavors. Perhaps most disturbingly, one perspective even sees a profit maximization logic as part of social entrepreneurship (Young and Lecy 2014). Since profit maximization implies the subordination of the social mission to profit interests, such a perspective even objectifies the stakeholders that are central for a social enterprise's mission and subordinates their needs and claims to profit interests. However, such a straight-forward economistic perspective is an exception rather than the rule. Often, mission-centric social entrepreneurship is implicitly economistic. In these cases, economic rationality is carried into social entrepreneurship through the maximization of something other than profit. This seems to follow the assumption that the entrepreneurial aspect of social entrepreneurship can only be the maximization principle. In order to achieve social entrepreneurship's 'social' 
mission, therefore, entrepreneurs should maximize something 'social' instead of profit. Some view the difference between regular for-profit firms and enterprises following a 'social' mission as the former's maximization of "value capture", while the latter maximize "value creation", thereby making value (allegedly) available for everyone (Santos 2012, p. 339). The idea of production output maximization by social enterprises follows a similar direction (Agafonow 2015).

Such modifications do not overcome the ethical shortcomings of economism but are a consequent application of economism to the social entrepreneurship context. The ethical difficulties of economism do not stem from the orientation towards self-interest but from the absolutization of one specific end through its maximization. Thus, replacing the end that is absolutized through its maximization with something 'social' does not change the basic ethical problem: The maximization of anything requires an actor to subordinate all conceivable claims to the particular interest that is to be maximized. It does not matter how 'social' the maximization objective is, as the regulative idea of maximizing anything carries an inherent relentlessness that causes immense ethical difficulties. If the maximization of $\mathrm{X}$ is the goal, then the maximization principle posits that the claims of any individuals are only considered if these individuals and their claims might hinder the maximization of $\mathrm{X}$, or if adhering to their claims may contribute to the maximization of $X$. In any other cases, individuals' claims are ignored a priori, thereby treating individuals "merely as a means" (Kant 1785/2012, p. 29) to the maximization of X. However, if individuals are treated "merely as a means" and not "as an end" (Kant $1785 / 2012$, p. 29), the proscription of objectifying individuals is breached. Whereas the pursuit of a particular interest is not illegitimate in itself, it becomes illegitimate if that particular interest becomes absolute through its maximization, as the maximization principle then supplants the moral principle (Thielemann 2009). Thus, we can reject any maximization approaches to social entrepreneurship, since the maximization of anything (even if it serves a noble goal like combating hunger) might collide with the legitimate claims of stakeholders involved in the production of the outcome to be maximized, which a truly social entrepreneur cannot legitimately dismiss from the outset.

Since mission-centric approaches that posit the maximization principle in social entrepreneurship inevitably build on economic rationality, the ethics underlying these approaches have economistic tendencies. When missioncentric conceptions import economism's maximization principle into social entrepreneurship, it implies that not only perfect duties are ignored, but that social entrepreneurs are freed from all duties, because they are only supposed to maximize their voluntarily chosen social mission objectives. Thus, anything that is not instrumental for the social mission is consequently ignored. Whereas in general mission-centric social entrepreneurship perfect duties stay unaddressed, while imperfect duties can in principle be incorporated into this conception, economistic social entrepreneurship does not acknowledge any duties, whether perfect or imperfect. Thus, in economistic social entrepreneurship the imperfect duty of managerial affability (Robinson 2019), for instance, is not respected either. In economistic social entrepreneurship, affable action may occasionally be taken by social entrepreneurs, if this is conducive to the maximization of the social mission's objective. However, if managerial affability never happens to be conducive to maximizing the social mission's objective, in economistic social entrepreneurship the social entrepreneur is not supposed to act affably at all. However, imperfect duties require that the principle of the imperfect duty itself is being respected (Hill 1971). If an agent's actions occasionally coincide with actions that could stem from an imperfect duty, but are only enacted out of instrumentalist deliberation and not because the agent acknowledges the imperfect duty as such, the imperfect duty itself is not respected. Thus, social entrepreneurship conceptions building on the maximization principle imply that perfect duties and imperfect duties are ignored, which is entirely in line with economism.

Frequently, researchers conceptualize social entrepreneurship as maximizing social impact instead of private value (e.g., Nicholls 2008). One could argue that the maximization of 'social impact' or 'value creation' is not a particular interest because it benefits everybody and therefore is immune to the critique presented above. However, both 'social impact' and 'value creation' are terms that need clarification. The maximization of anything requires a precise understanding of what is to be maximized in advance, be it social impact or social value. Social enterprises define for themselves what social impact means to them and measure it accordingly (Molecke and Pinkse 2017). While defining an enterprise's social impact, it is impossible to anticipate all the conceivable legitimate claims that a social enterprise might face, in the present or in future. Hence, the definition of any item to maximize can only be particularistic. Furthermore, any kind of maximization also implies that there are costs that need to be minimized, even in the case of 'social impact', but the possible ethical legitimacy of these costs (e.g., income securing the livelihood of suppliers) is systematically dismissed. Maximization approaches inevitably absolutize the object of maximization, thereby neglecting the moral principle (Ulrich 2008a), and ignoring perfect and imperfect duties. Thus, attempts to define a maximization object as broadly as possible cannot cure the ethical flaw inherent in the maximization principle. 


\section{Utilitarian Tendencies}

Approaches maximizing or oriented towards 'social value' have also a utilitarian connotation, implying that the maximization is not a question of personal preferences but one of a duty towards a virtual subject - the 'world' (Thielemann 2010b, p. 293). Utilitarianism is already deficient on a purely formal level. The formal problem in utilitarianism, as in any approach to social entrepreneurship that conceptualizes social enterprises as maximizing social impact, is the skewed distribution of moral rights and moral duties. Whereas in a utilitarian conception it is the duty of all individuals to contribute to the maximization of social value in the 'world', no single individual can derive any rights from that; the only subject holding moral rights in this ethics is a virtual subject referred to as the 'world' (Thielemann 2010b). This raises the question whether an ethics only distributing moral duties among individuals, without granting moral rights to any individual directly, is ethically sound. Furthermore, the utilitarian duty to contribute to the maximization of social value in the 'world' implies that an individual is obliged to sacrifice him- or herself if the overall increase of social value in the 'world' outweighs his or her decrease in social value through that sacrifice. In the most extreme case, utilitarian reasoning would deem a situation ethically legitimate in which $99 \%$ of earth's population have to make sacrifices if the benefits gained by the remaining $1 \%$ are so large that they outweigh the accumulated sacrifices of the $99 \%$. Such an offset of sacrifices and benefits is highly problematic from any non-utilitarian deontological-ethical point of view, as it ignores the moral rights of those individuals that endure sacrifices (Thielemann 2010b). The creation of a virtual macro subject as the sole holder of moral rights is already questionable (Thielemann 2010b), since there is no obvious reason why moral rights shouldn't be held by individuals directly. Since no individual is guaranteed moral rights in utilitarianism, the dignity of individuals is open to disposition if their sacrifice for a greater good leads to an overall increase in social value or welfare (Ulrich 2008a). When put under ethical scrutiny, utilitarianism unveils some inherent ethical difficulties that transfer to social entrepreneurship whenever mission-centric social entrepreneurship is understood as a utilitarian endeavor, e.g., through social impact maximization.

Mission-centricity in social entrepreneurship does not imply economism or utilitarianism directly. However, this popular stream of social entrepreneurship studies blanks out the perfect duties of social entrepreneurs entirely, which is a conducive context for economistic and utilitarian approaches to foster, including the ethical difficulties that these approaches bring about. Especially with regard to the economistic confusions that come along with parts of mission-centric social entrepreneurship, the question arises as to whether social entrepreneurship can even contribute to overcoming the societal grievances it addresses when understood in the mission-centric sense. In mission-centric social entrepreneurship, all enterprises are focused exclusively on their unavoidably particularistic social missions. Consequently, in the most cynical example, those social enterprises addressing poverty could cause health issues through their working conditions and those addressing health issues might use exploitative supply-chains, thus increasing poverty. Viewed holistically, mission-centricity incorporates the danger of social enterprises contributing to societal grievances that other social enterprises are addressing. Thus, we need an alternative conception of social entrepreneurship, which ensures that the enterprises to which we ascribe the normatively charged label of being 'social' not only address certain societal grievances in their social missions but also insure that they do not contribute to further grievances through the way they operate.

\section{Broadening the Perspective: An Integrative Economic Ethics View on Social Entrepreneurship}

The fact that the social entrepreneurship discipline is still in its early stages of development renders it still possible to contribute to the normative underpinnings of this concept. To conceptualize a kind of social entrepreneurship that lives up to its inherent normative validity claim, we need a clarification and an ethical readjustment of what it involves. From an integrative ethics perspective, the question whether a mission qualifies as social is far less central. The focal point, according to integrative ethics, is that the "pursuit of success and profit must be categorically subordinated to the normative precondition of legitimacy" (Ulrich 2008a, p. 408). This refers to the perfect duties (Kant 1785/2012) of social entrepreneurs, because only the normative precondition of legitimacy protects the stakeholders of an enterprise from being treated merely as a means to the end of profit or success (Thielemann 2010a). This implies that social enterprises act moderately, reflecting on their economic activities and making sure they achieve success exclusively with means that are socially meaningful and ethically legitimate (Ulrich 2008a). The categorical subordination of the pursuit of success to the normative precondition of legitimacy extends far beyond the narrow scope of an organization's mission, since it is categorical and thus by definition also touches on mission-unrelated areas.

In this paper, we argue that the concept of practices is helpful to operationalize this categorical subordination on the level of organizations. Practices are a "temporally evolving, open-ended set of doings and sayings linked by practical understandings, rules, teleoaffective structure, and general 
understandings" (Schatzki 2002, p. 87). Even though integrative ethics does not relate to the concept of practice, we introduce it here because it sensitizes us to ethical elaboration when regarding organizational contexts such as social enterprises. Especially the notion of teleoaffectivity within practice is fruitful in this regard. Teleoaffectivity refers to the normativity of a practice in the senses of acceptable behavior and oughtness (Schatzki 2002). This connects to Rouse's (2001) idea that the normativity of practice surfaces in the distinction between correct and incorrect practice.

We argue that practices are a locus of morality and that organizational practices reflect the morality of an organization, which might differ from the moral convictions of its individual members. In a similar vein, Dey and Steyaert (2016) argue that, in social entrepreneurship, ethics is not situated in the properties of individuals, but in practice. Without following Dey and Steyaert's Foucauldian notion of ethics explicitly, we connect to the idea that there is something to gain when focusing on the supra-individual level of practices. The normative oughtness of an organizational practice guides the doings and sayings of organizational members. Thus, it is possible that organizational members carry out a practice in a certain way, even though their personal moral convictions may diverge from the moral substance of the organizational practice itself.

When speaking of ethically legitimate social entrepreneurship, organizational practices are a helpful concept, since they are the carriers of normativity on a supra-individual level. This implies that Ulrich's (2008a) categorical subordination of the pursuit for success to the normative precondition of legitimacy can be operationalized in terms of practices. On an abstract level, this means that social entrepreneurship practices need to exhibit an oughtness to consider legitimate aspects extraneous to profitability and mission success. Consequently, each practice in a social entrepreneurial context should involve an element of oughtness regarding the consideration of legitimate claims by those possibly affected by that specific practice. This contrasts strongly with an oughtness oriented mainly towards efficiency or profit maximization, as taught in business schools and prevalent in many organizations (Huehn 2008; Hühn 2014). However, the pursuit of efficiency and profit does not need to be abandoned altogether in social entrepreneurship. It only means that, in ethically reflected social entrepreneurship, the pursuit of efficiency, profit or mission success is bound by its enactment through practices involving an oughtness regarding the consideration of legitimate aspects extraneous to profitability and mission success. More concretely, such an oughtness may become apparent in the way different practices are carried out. For example, an enterprise carrying out the practice of paying suppliers' bills with an oughtness as described above would entail correcting the supplier after a mistake in an invoice to the supplier's disadvantage. Another example might be the practice of business traveling. A consideration of aspects extraneous to profitability and mission success would imply not using the cheapest means of traveling, but the one causing the least environmental damage that is feasible given the time and budget available. Consequently, such practices reproduce exchange relations (to customers, suppliers, employees etc.) that have the capacity of entailing values such as fairness or solidarity.

Even though the 'social' mission in social entrepreneurship already provides some guidance, the actual meaning of 'social' is mostly underdeveloped (Barinaga 2012). We propose to conceptualize social enterprises and social entrepreneurship as addressing societal grievances in their missions. First, the term 'societal grievance' subsumes social and ecological aspects, since ecological grievances stem from society's actions as well. Thereby, we consciously include missions centered on ecological issues. Second, the term grievance implies that help is required. Thus, social entrepreneurs addressing a societal grievance in their mission act upon the imperfect duty of beneficence. Since the duty of beneficence belongs to the imperfect duties with the most latitude (Hill 1971), social entrepreneurs have a high degree of freedom to choose which societal grievances they want to address in their missions. Consequently, many different social missions are possible that are all ethically legitimate.

Though social entrepreneurship does not require a certain organizational form, the typical entity of social entrepreneurship is a social enterprise. Social entrepreneurship is carried out on the whole by social enterprises. There is no requirement to exclude any organizational forms as long as there is economic activity involved, which delimits social entrepreneurship from philanthropic or non-profit organizations (Saebi et al. 2018). More precisely, the existential significance of economic exchange relations defines the entrepreneurial aspect of social entrepreneurship. It is important, however, that these economic exchanges are primarily in place to address societal grievances in order to qualify as being socially entrepreneurial.

The practices of ethically legitimate social entrepreneurship do not need to be limited to the scope of entrepreneurial activity. Integrative ethics proposes a multi-faceted approach for businesses: on the one hand, contributing to a life-serving economy by occupying a legitimate function in society and acting responsibly in business actions and interaction (practices); on the other hand, engaging in republican corporate citizenship by actively lobbying for political reforms of the regulatory framework in order to ensure that actors who want to act responsibly in the market do not get worn down by competitive pressures (Ulrich 2008a). Accordingly, a social enterprise should engage in political activity as well, but additionally aiming towards regulatory reforms in order to fight the societal grievances addressed by the social 
enterprise more effectively. While striving for effectiveness, social enterprises should not fall for effectiveness maximization. Instead, well-understood social entrepreneurship should cultivate effectiveness monitoring practices which increase the organization's reflexivity. This makes it possible to determine whether the addressed societal grievances really have been diminished. However, the reflexive monitoring simultaneously ensures that the pursuit of effectiveness does not violate the legitimate claims of stakeholders outside the realm of the addressed societal grievances. Since stakeholder claims are not obvious in any situation, social enterprises should engage in dialogue with different stakeholder groups from a communication-oriented perspective (Habermas 1989) to discursively facilitate the assessment of the ethical legitimacy of stakeholder claims.

It could be possible, however, that social entrepreneurs face such competitive pressures that they are no longer able to consider all of the stakeholder claims they acknowledge as being legitimate. To demand that a social entrepreneur engages in self-sacrifice in order to consider all legitimate stakeholder claims may simply be beyond ethical exigibility. There is some evidence that this is frequently the case, leading to overworked, self-exploiting social entrepreneurs (Dempsey and Sanders 2010). Hence, it is crucial that ethical responsibility is not passed on to individual entrepreneurs or organizations entirely, but that regulatory ethics also prevail to enable a wider scope of responsible agency in the first place (Ulrich 2008a; Thielemann 2010a). Social enterprises in particular could benefit from a regulatory framework enhancing the ethically legitimate agency of organizations, thereby allowing them to foster practices that cater to the well-being of mission-unrelated stakeholders as well.

\section{Distinctions Based on Mission and Practices: A Typology of Enterprise Forms}

As laid out above, integrative ethics shift our attention to considerations extraneous to profitability as well as mission success alone. Whether an enterprise can claim ethical legitimacy depends on its practices and the degree to which legitimate aspects extraneous to profitability and mission success are considered there. Overcoming the limits of mission-centricity by widening the horizon to include practices adds an ethically crucial dimension to the conception of social entrepreneurship. Viewing both mission and practice dimensions simultaneously, a typology unfolds that can help to distinguish social enterprises more accurately from other enterprise forms. An enterprise's practices can have an oughtness regarding the moral principle, expressed through a consideration of aspects extraneous to profitability and mission success. Alternatively, practices can have an oughtness regarding the maximization principle, expressed through profit maximization, social impact maximization, etc. The distinction in the mission dimension follows social entrepreneurship literature and considers whether an enterprise's mission addresses societal grievances or not. As depicted in Fig. 1, the transitions between the two extremes are gradual in both dimensions. This implies that the four enterprise forms identified in this typology are ideal types (Weber 1978) while constellations between them are likely. Just as societal grievances might play a bigger or smaller role in an enterprise's mission, an enterprise's practices may have a stronger or lesser oughtness regarding the maximization of certain outcomes.

As discussed above, a social enterprise's practices involve an oughtness to consider legitimate aspects extraneous to profitability and mission success, while its mission addresses societal grievances. If we understand social entrepreneurship as something social enterprises actually do, we can define it as an entrepreneurial endeavor addressing societal grievances with practices that consider aspects extraneous to profitability and mission success, rather than striving to maximize particularistic outcomes.

It is difficult to find examples illustrating the ideal types stemming from the typology, as both dimensions are gradual and convincing examples need to be extreme cases in two ways. Besides, determining the oughtness entailed in an enterprise's practices requires profound knowledge of these practices. To illustrate the ideal types, we will settle for examples based on self-presentations that hint how their practices might be. However, it is not possible to tell for sure whether these examples are indeed as close to the ideal types as it appears from the outside.

The enterprise GEPA, located in Germany, may well come close to the ideal type of a social enterprise. GEPA engages in fair trade to help impoverished farmers of the Global South. To protect farmers from volatile world market prices, GEPA pays them a minimum price, which is enough to ensure their livelihoods. If the world market price rises, the farmers are paid the market price for their goods. GEPA's trade principles clearly signal the consideration of aspects extraneous to profitability and, if these are also translated into practice, would qualify GEPA as a social enterprise (also because GEPA's mission primarily addresses societal grievances). GEPA stands out because it also shows republican corporate citizenship (Ulrich 2008a) by actively lobbying for fairer global trade conditions (GEPA mbH 2019).

The second ideal type is the moderate enterprise, which only differs from social enterprises in its mission focus. Instead of addressing societal grievances, a moderate enterprise addresses other aims. Since the moderate enterprise's practices are guided by ethical judgment, this influences its practices of (re)defining a mission. Hence, the aims addressed by a moderate enterprise in its mission have a function in society and are not illegitimate in themselves. 
Fig. 1 Typology of different enterprise forms derived from mission and practices

\section{Practices}

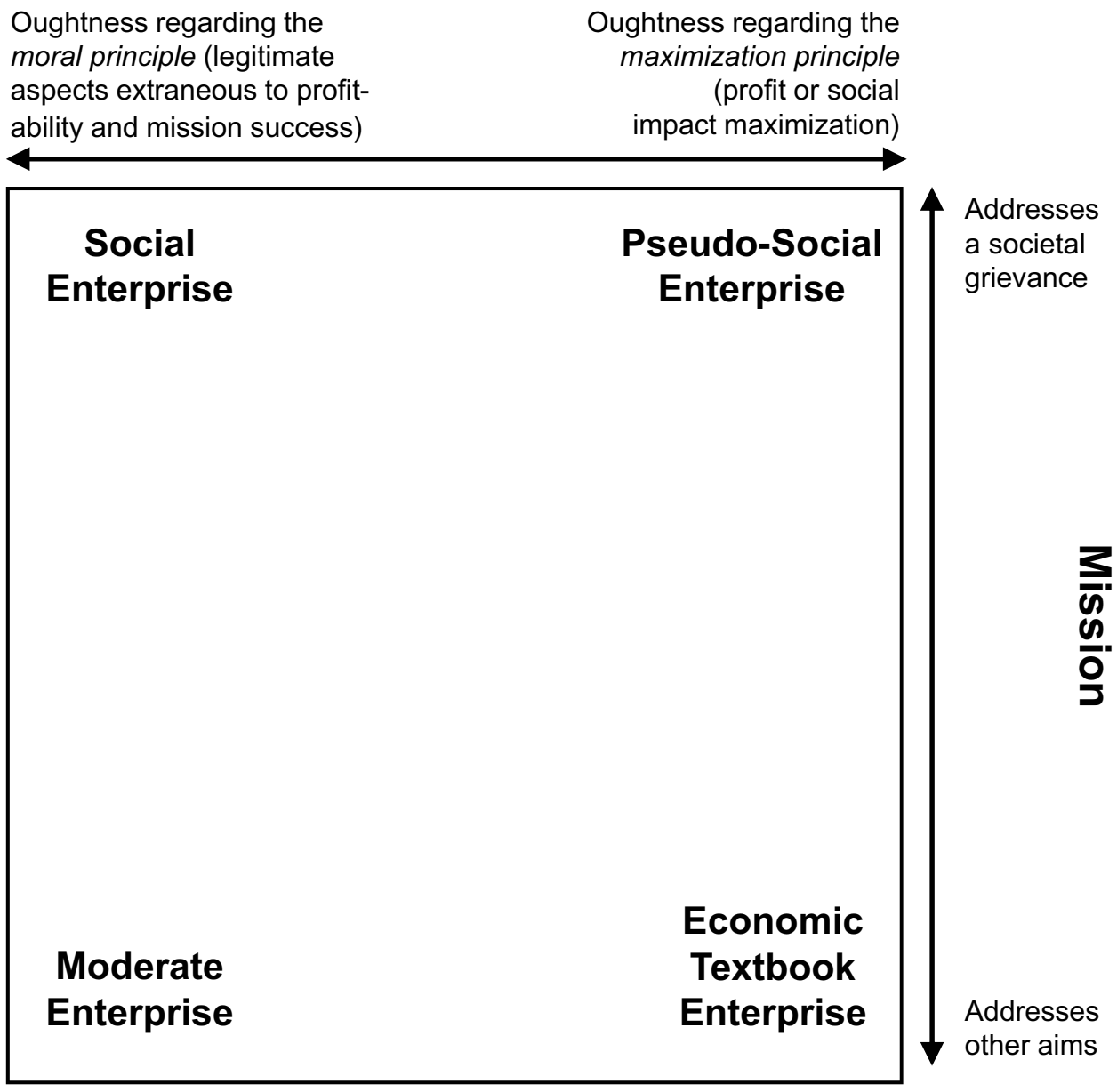

An illustrative example of this type of enterprise is CKS Schuhsenkel, a German producer of shoelaces, managed by a CEO who claims that they are not aiming to achieve the highest profit possible (Bernert 2016). Since the production of shoelaces does not address a societal grievance, this company is a moderate enterprise. This type of enterprise plays the important part of an ethical role model in the economy. By showing that you do not have to be a social enterprise in order to contribute to a life-serving economy, it can inspire 'regular' enterprises to contribute to societal well-being by becoming more moderate (with regard to profit-seeking) in their practices.

In contrast to moderate enterprises, economic textbook enterprises do not consider a single genuine aspect extraneous to profitability in their practices and fully embrace economic rationality, just as (micro) economic textbooks suggest. The practices of this type of enterprise are geared entirely towards profit maximization, or are ethically unreflecting to such a degree that the legitimacy of stakeholders' claims is systematically left unconsidered. The gradual difference along the practice dimension can be interpreted as the degree to which aspects extraneous to profitability are eliminated from an enterprise's practices (Thielemann 2000). It is difficult to find such a radical example that would live up to the demands of ethical ignorance raised by textbook economics. Perhaps Amazon could serve as an example, since its treatment of employees and its tax evasion tactics do not display any regard for aspects extraneous to profitability (Mayr 2013). Companies following an instrumentalist approach to CSR (Gao and Bansal 2013) come close to this ideal type as well. Since they take CSR measures only to reach higher profits or to avoid losses, their CSR-practices are driven more by profit maximization than by anything else. Most 'regular' enterprises that do not question the maximization principle but still have a sense of morality might range somewhere in between the economic textbook enterprise and the moderate enterprise.

The last ideal type in this typology is the outcome of a misunderstanding. It does indeed address a societal grievance in its mission, by using practices that are ethically unreflecting to such a degree, however, that it cannot live up to its own aspiration of truly social entrepreneurship. This ideal type is called pseudo-social enterprise, because addressing societal grievances in a mission is frequently 
regarded as being an adequate way of identifying a social enterprise. No matter how noble the beneficent ends might be that an enterprise pursues in its social mission, it cannot live up to the claim of being truly social if, for instance, its staffing practices discriminate against minorities. An example that comes close to this ideal type is the One Acre Fund, with the mission to make African farmers more prosperous (One Acre Fund 2019c). One Acre Fund tries to achieve this objective by offering farmers financing, seeds and fertilizers, giving them training and facilitating sales in order to "maximize profits" for farmers (One Acre Fund 2019b). On the one hand, the help given to promote maximization is geared towards teaching farmers the radicalism needed to succeed in the market and, thereby, become bound entirely into an economistic logic. On the other hand, those farmers who are either unable or unwilling to become One Acre Fund's customers are left out systematically. Moreover, One Acre Fund's customers' profit-maximizing practices may set other farmers under competitive pressure to such an extent that their means of existence might be threatened. As opposed to organizations like 'Brot für die Welt' from Germany, which also supports African farmers, One Acre Fund concentrates on growth, pursuing an "expansion strategy" (One Acre Fund 2019a). A start up aiming at growth at the expense of other organizations, addressing the same grievances and spreading profit-maximizing behaviors, is no more than a pseudo-social enterprise. If we conceptualize social entrepreneurship so broadly that this concept also encompasses enterprises such as the One Acre Fund, it comes as no surprise that researchers criticize social entrepreneurship for contributing to marketization and commodification (Eikenberry and Kluver 2004; Garrow and Hasenfeld 2014).

This typology sensitizes that social enterprises and moderate enterprises are morally legitimate, because these enterprise forms comply with perfect duties, which is reflected in their practices. The only difference between these two is their different approach regarding the imperfect duty of beneficence, which is reflected in their missions. While social entrepreneurs decide to promote the objective of being beneficent in their enterprise's missions, entrepreneurs from moderate enterprises do not decide to promote such an objective within their entrepreneurial realm. Pseudo-social enterprises and economic textbook enterprises, on the other hand, are morally illegitimate, because they neglect their perfect duties, which is reflected in their maximization-oriented practices. It is important to underscore that the enterprise forms identified in this typology are Weberian ideal types (Weber 1978), meaning that empirical enterprises are likely to be less pronounced in the two dimensions than the ideal types presented here.

\section{Discussion and Concluding Remarks}

Social entrepreneurship is a normative concept, since the prefix 'social' carries the normative validity claim of being good entrepreneurship, thereby delimiting social entrepreneurship from business entrepreneurship. It therefore becomes necessary to reason normatively as to what may be subsumed under the term social entrepreneurship and what should be excluded from it. A prominent view on social entrepreneurship grounds its social dimension exclusively on a social mission (e.g., Dees 2001; Mair and Martí 2006; Nicholls 2008). Such a mission-centric conception of social entrepreneurship is fundamentally misleading because it grants the normatively charged prefix 'social' while systematically dismissing all claims of mission-unrelated stakeholders. However, mission-unrelated stakeholders may also have legitimate claims that cannot be dismissed from the outset by a truly social enterprise. The root of the ethical problem in mission-centric social entrepreneurship is an over-emphasis of imperfect duties, which leads to the ignoring of perfect duties. The blanking out of perfect duties opens the gate for missioncentric conceptions building on the maximization principle, which carries economism into social entrepreneurship studies. Whereas in economism agents are only supposed to maximize their self-interest (Ulrich 2008a), in economistic social entrepreneurship agents are only supposed to maximize their voluntarily chosen social missions. A social mission fits perfectly into the economistic paradigm because it can be broken down to an agent's preferences within the logic of self-interest maximization. Economistic social entrepreneurship conceptions blank out perfect duties and imperfect duties via the maximization principle, which leaves no room for duty-related considerations. In some cases, economism is accompanied by utilitarianism, when the maximization object is general 'social impact' (Nicholls 2008).

Such a mission-centric conception of social entrepreneurship is not only ethically misleading but also misguided, as it lacks a holistic perspective on social entrepreneurship as a phenomenon. Whereas social entrepreneurship is supposed to reduce societal grievances, a mission-centric conception reaches its limits fast. If every social enterprise and every social entrepreneur focused entirely and exclusively on their unavoidably particularistic social missions, it is possible that they would succeed in reducing societal grievances within their missions' scopes, but at the cost of greatly contributing to societal grievances outside the scopes of their unavoidably particularistic social missions. A mission-centric conception of social entrepreneurship cannot ensure, for instance, that a social enterprise pursuing the mission of reducing poverty 
does not contribute enormously to environmental degradation (which lies outside its mission's scope) in the process, or vice versa. This point connects to Martí's (2018) critique that some social enterprises follow exclusionary business models that address societal problems, but at the same time exclude some stakeholders they intend to help. Whereas Martí points to possible exclusionary problems within the mission-centric view of social entrepreneurship, we argue that through a mission-centric view such exclusions happen systematically to mission-unrelated stakeholders voicing equally pressing and legitimate claims.

As Hervieux and Voltan (2018) have depicted, the social entrepreneurship movement aspires to become systemchanging. We argue that social entrepreneurship is unable to release its system-changing potential when it is conceptualized with its mission-centric ethical shortcomings. Many of the grievances addressed in social entrepreneurship (e.g., climate change or poverty) come into being partly because of the relentlessness of organizations pursuing profit maximization. If social entrepreneurship follows the same maximization principle (as often implied in mission-centric social entrepreneurship), it systematically becomes part of the problem and not part of the solution. Each maximization approach is unavoidably particularistic and logically implies indifference towards anything that is unrelated to the particularistic object of maximization. Thus, social entrepreneurship research needs to overcome maximization approaches to unlock its potential to combat the formation of societal grievances and not only tackle a few arbitrary symptoms. Due to double hermeneutics (Giddens 1979) a misleading theoretical conception of social entrepreneurship like the mission-centric one is likely to be carried performatively (Ghoshal 2005; Ferraro et al. 2005) into social entrepreneurship practice. Thus, social entrepreneurship research needs to develop a more holistic conception of social entrepreneurship, which does not ground social entrepreneurship's social dimension on a social mission alone. Otherwise, it will run into the danger of performatively (and perhaps unintentionally) turning social entrepreneurship practice into a snake that bites its own tail.

We follow the argument of Siqueira et al. (2018) that social enterprises require adjusted theories, and cannot be grasped via generic business theories. This supports the idea of not importing economistic conceptions from business and economics into social entrepreneurship studies. Thus, we propose conceiving social entrepreneurship based on practices that can live up to the normative validity claim of good entrepreneurship, which is inherent in the prefix 'social', and on a mission addressing societal grievances. This implies that social entrepreneurship practices have an oughtness regarding the consideration of aspects extraneous to profitability and mission success. Such a conception is ethically sounder because it does not dismiss certain stakeholder claims from the outset but allows the incorporation of claims from all conceivable stakeholders based on their ethical legitimacy. This implies that the perfect as well as the imperfect duties (Hill 1971) of social entrepreneurs are reflected in this conception, which includes duties towards mission-unrelated stakeholders as well.

Locating the social dimension of social entrepreneurship in practices as well as in a mission not only clarifies social entrepreneurship conceptually but also allows us to delimit social enterprises from other enterprise forms. Whereas hitherto only the mission dimension has distinguished social enterprises from 'regular' enterprises, the addition of a practice dimension allows for a more fine-grained distinction. Especially with regard to change processes of social enterprises, the practice dimension of the typology in Fig. 1 opens up new angles for research. In light of the typology, the concept discussed as mission drift appears in a different light. Mission drift is referred to as a change process whereby a social enterprise has deviated from its main purpose or social mission (e.g., Cornforth 2014). However, once a social mission is no longer the only constitutive feature of truly social enterprises, the process of a social enterprise becoming more similar to a regular enterprise implies not only a change in mission, but also a change in practices. In addition, a pure practice drift is thinkable, whereby the mission remains unchanged but the social enterprise slowly becomes a pseudo-social enterprise.

Furthermore, the typology points to two enterprise forms that have not been so prominent on the scholarly radar: moderate enterprises and pseudo-social enterprises. Pseudosocial enterprises are a fruit of misunderstood (economistic) social entrepreneurship lacking a holistic perspective. We can gain clarity if we stop lumping social enterprises and pseudo-social enterprises together. Against this background, critique voiced towards social enterprises (e.g., Garrow and Hasenfeld 2014; Eikenberry and Kluver 2004) might be directed mainly towards pseudo-social enterprises. The moderate enterprise, on the other hand, identifies an enterprise form that exhibits practices associated with the image of an honorable merchant. This enterprise form reminds us that there are enterprises which are not entirely and exclusively driven by profit deliberations, but which have non-negotiable principles that surface in these enterprises' practices. Even though these enterprises do not address societal grievances, they contribute to a life-serving economy by conducting their businesses in ethically legitimate ways.

The integrative economic ethics perspective sensitizes us to the fact that practices matter in the pursuit of a lifeserving economy, instead of simply applauding how nowadays many enterprises address societal grievances. A focus on the practice dimension teaches us that it is more crucial for enterprises to become more moderate by considering aspects extraneous to profitability (or extraneous to mission 
success) and that there is a need for a regulatory framework to ensure that those acting moderately are not worn down by competitive pressures (Ulrich 2008a). This is especially important, bearing in mind how demanding social entrepreneurship is for social entrepreneurs. They need to reflexively monitor their effectiveness, try to limit possible unintended consequences of their actions, permanently weigh (possibly conflicting) claims of stakeholders, and at the same time withstand the pressure to obtain the resources needed for economic viability (Ulrich 2008b).

This paper does not present an entirely elaborated integrative ethics of social entrepreneurship; rather, it is a first attempt to grasp social entrepreneurship from this perspective. Nevertheless, the explicit ethical grounding that integrative ethics provides for social entrepreneurship can be a helpful normative basis, to which alternative understandings of social entrepreneurship, which are not mission-centric can connect (e.g., Defourny and Nyssens 2012). The developed typology only entails extreme ideal types, whereas it might be interesting to take constellations between the extremes into consideration. Furthermore, the application of the typology for classifying empirical cases is methodically challenging, since the consideration of aspects extraneous to success in an organization's practices can be grasped better using ethnographic methods rather than quantitative approaches.

The paths for further research derived from this paper center around the need to explicate further the integrative ethics conception of social entrepreneurship. In light of the accusation of social entrepreneurship contributing to marketization and commodification (e.g., Garrow and Hasenfeld 2014; Eikenberry and Kluver 2004), further elaboration is needed to develop a social entrepreneurship concept that does not contribute to either of the two. The role of political action within social entrepreneurship is also a promising avenue for research, since the possibilities to diminish societal grievances exclusively through entrepreneurial activity appear limited. Furthermore, an investigation into the related but more refined concept of social business (Yunus 2010; Yunus et al. 2010) regarding its normative foundations appears equally promising. As indicated above, the combination of integrative ethics with a theory of practice is generally possible. Therefore, the complementarity of integrative ethics and different theories of practice (cf. Nicolini 2012) should be elaborated upon. The typology developed raises questions of (possibly unintended) transitions between the enterprise forms over time, inviting theorization of different change trajectories and observation of the dimensions of mission and practices when engaging empirically with (social) enterprises in longitudinal research.

With this paper, we contribute to the literature on social entrepreneurship in several ways. First, we explicate how a prominent part of social entrepreneurship research builds on a mission-centric conception, and unearth the ethical difficulties of such a perspective. Second, we ground social entrepreneurship normatively on practices that can legitimately qualify as social and on a social mission. Thereby, we shift the focus onto social entrepreneurship practices that are conceptually equally important for overcoming the societal grievances social enterprises address in their social missions. Third, by adding a practice dimension, we develop a two-dimensional typology that contributes to a more finegrained distinction of social enterprises from other enterprise forms and puts two enterprise forms on the map that have not featured very prominently in research so far-moderate enterprises and pseudo-social enterprises. Moreover, this typology can serve as a canvas to plot changes of social enterprises over time and so help to develop more nuanced accounts of drift in social entrepreneurship.

Acknowledgements I want to thank Jörg Sydow and Ulrich Thielemann, who commented on earlier versions of this paper. I also thank the editor Sara Louise Muhr and four anonymous reviewers for their insightful and constructive suggestions.

Funding Open Access funding provided by Projekt DEAL.

\section{Compliance with Ethical Standards}

Conflict of interest The authors declare that they have no conflict of interest.

Open Access This article is licensed under a Creative Commons Attribution 4.0 International License, which permits use, sharing, adaptation, distribution and reproduction in any medium or format, as long as you give appropriate credit to the original author(s) and the source, provide a link to the Creative Commons licence, and indicate if changes were made. The images or other third party material in this article are included in the article's Creative Commons licence, unless indicated otherwise in a credit line to the material. If material is not included in the article's Creative Commons licence and your intended use is not permitted by statutory regulation or exceeds the permitted use, you will need to obtain permission directly from the copyright holder. To view a copy of this licence, visit http://creativecommons.org/licenses/by/4.0/.

\section{References}

Agafonow, A. (2015). Value creation, value capture, and value devolution: Where do social enterprises stand? Administration \& Society, 47, 1038-1060. https://doi.org/10.1177/0095399714555756.

Alter, S. K. (2008). Social enterprise models and their mission and money relationships. In A. Nicholls (Ed.), Social entrepreneurship: New models of sustainable social change (pp. 205-232). Oxford: Oxford University Press.

Alvord, S. H., Brown, L. D., \& Letts, C. W. (2004). Social entrepreneurship and societal transformation. The Journal of Applied Behavioral Science, 40, 260-282. https://doi.org/10.1177/00218 86304266847.

Andersson, F. O., \& Self, W. (2015). The social-entrepreneurship advantage: An experimental study of social entrepreneurship and perceptions of nonprofit effectiveness. VOLUNTAS: 
International Journal of Voluntary and Nonprofit Organizations, 26, 2718-2732. https://doi.org/10.1007/s11266-014-9543-1.

Apel, K.-O. (1987). Fallibilismus, Konsenstheorie der Wahrheit und Letztbegründung. In W. R. Köhler, \& Forum für Philosophie Bad Homburg (Eds.), Philosophie und Begründung (pp. 116-211). Frankfurt am Main: Suhrkamp.

Apel, K.-O. (1998). Towards a transformation of philosophy. Milwaukee: Marquette University Press.

Austin, J., Stevenson, H., \& Wei-Skillern, J. (2006). Social and commercial entrepreneurship: Same, different, or both? Entrepreneurship Theory and Practice, 30, 1-22. https://doi.org/10.111 1/j.1540-6520.2006.00107.x.

Barendsen, L., \& Gardner, H. (2004). Is the social entrepreneur a new type of leader? Leader to Leader. https://doi.org/10.1002/ltl.100.

Barinaga, E. (2012). Overcoming inertia: The social question in social entrepreneurship. In D. Hjorth (Ed.), Handbook on organisational entrepreneurship (pp. 242-256). Cheltenham: Edward Elgar Publishing.

Bernert, W. (2016). Anders wirtschaften - nicht alle Unternehmen wollen wachsen. Deutsche Welle. Retrieved June 21, 2019, from https://www.dw.com/de/anders-wirtschaften-nicht-alle-unter nehmen-wollen-wachsen/av-19255238.

Certo, S. T., \& Miller, T. (2008). Social entrepreneurship: Key issues and concepts. Business Horizons, 51, 267-271. https://doi. org/10.1016/j.bushor.2008.02.009.

Chell, E. (2008). Social enterprise and entrepreneurship: Towards a convergent theory of the entrepreneurial process. International Small Business Journal, 25(1), 5-26.

Cochran, P. (2007). The evolution of corporate social responsibility. Business Horizons, 50, 449-454. https://doi.org/10.1016/j.busho r.2007.06.004.

Conway Dato-on, M., \& Kalakay, J. (2016). The winding road of social entrepreneurship definitions: A systematic literature review. Social Enterprise Journal, 12, 131-160. https://doi.org/10.1108/ SEJ-06-2015-0016.

Cornforth, C. (2014). Understanding and combating mission drift in social enterprises. Social Enterprise Journal, 10, 3-20. https:// doi.org/10.1108/SEJ-09-2013-0036.

Dacin, P., Dacin, M. T., \& Matear, M. (2010). Social entrepreneurship: Why we don't need a new theory and how we move forward from here. Academy of Management Perspectives, 24(3), 37-57.

Dees, J. G. (2001). The meaning of social entrepreneurship. Retrieved February 7, 2017, from https://centers.fuqua.duke.edu/case/wpcontent/uploads/sites/7/2015/03/Article_Dees_MeaningofSocial Entrepreneurship_2001.pdf.

Defourny, J., \& Nyssens, M. (2012). The EMES approach of social enterprise in a comparative perspective. Retrieved September 3, 2015, from https://emes.net/content/uploads/publications/EMESWP-12-03_Defourny-Nyssens.pdf.

Dempsey, S. E., \& Sanders, M. L. (2010). Meaningful work? Nonprofit marketization and work/life imbalance in popular autobiographies of social entrepreneurship. Organization, 17(4), 437-459.

Dey, P., \& Steyaert, C. (2012). Social entrepreneurship: Critique and the radical enactment of the social. Social Enterprise Journal, 8 , 90-107. https://doi.org/10.1108/17508611211252828.

Dey, P., \& Steyaert, C. (2016). Rethinking the space of ethics in social entrepreneurship: Power, subjectivity, and practices of freedom. Journal of Business Ethics, 133, 627-641. https://doi. org/10.1007/s10551-014-2450-y.

Dey, P., Schneider, H., \& Maier, F. (2016). Intermediary organisations and the hegemonisation of social entrepreneurship: Fantasmatic articulations, constitutive quiescences, and moments of indeterminacy. Organization Studies, 37, 1451-1472. https://doi. org/10.1177/0170840616634133.

Douglas, H. (2000). Inductive risk and values in science. Philosophy of Science, 67, 559-579. https://doi.org/10.1086/392855.
Drucker, P. F. (1973). Management: Tasks, responsibilities, practices. New York: Harper \& Row.

Ebrahim, A., Battilana, J., \& Mair, J. (2014). The governance of social enterprises: Mission drift and accountability challenges in hybrid organizations. Research in Organizational Behavior, 34, 81-100. https://doi.org/10.1016/j.riob.2014.09.001.

Eikenberry, A. M., \& Kluver, J. D. (2004). The marketization of the nonprofit sector: Civil society at risk? Public Administration Review, 64(2), 132-140.

Ferraro, F., Pfeffer, J., \& Sutton, R. (2005). Economics language and assumptions: How theories can become self-fulfilling. Academy of Management Review, 30, 8-24. https://doi.org/10.2139/ ssrn.521883.

Fowler, A. (2000). NGDOs as a moment in history: Beyond aid to social entrepreneurship or civic innovation? Third World Quarterly, 21(4), 637-654.

Freeman, R. E. (1994). The politics of stakeholder theory: Some future directions. Business Ethics Quarterly, 4, 409-421. https ://doi.org/10.2307/3857340.

Friedman, M. (1970). The social responsibility of business is to increase its profits. The New York Times Magazine.

Gao, J., \& Bansal, P. (2013). Instrumental and integrative logics in business sustainability. Journal of Business Ethics, 112(2), 241-255.

Garrow, E. E., \& Hasenfeld, Y. (2014). Social enterprises as an embodiment of a neoliberal welfare logic. American Behavioral Scientist, 58(11), 1475-1493.

GEPA mbH. (2019). GEPA-Kriterien für Fairen Handel. Retrieved June 21, 2019, from https://www.gepa.de/gepa/mission/gepakriterien.html.

Ghoshal, S. (2005). Bad management theories are destroying good management practices. Academy of Management Learning \& Education, 4(1), 75-91.

Giddens, A. (1979). Central problems in social theory: Action, structure and contradiction in social analysis. London: Macmillan.

Greenwood, M., \& Freeman, R. E. (2018). Deepening ethical analysis in business ethics. Journal of Business Ethics, 147, 1-4. https://doi.org/10.1007/s10551-017-3766-1.

Habermas, J. (1988a). Moralität und Sittlichkeit: Treffen Hegels Einwände Gegen Kant auch auf die Diskursethik zu? Revue Internationale de Philosophie, 42(166(3)), 320-340.

Habermas, J. (1988b). On the logic of the social sciences. Cambridge, MA: MIT Press.

Habermas, J. (1989). The theory of communicative action: The critique of functionalist reason (Vol. 2). Cambridge: Polity Press.

Habermas, J. (1990). Moral consciousness and communicative action (Studies in contemporary German social thought). Cambridge, MA: MIT Press.

Hervieux, C., \& Voltan, A. (2018). Framing social problems in social entrepreneurship. Journal of Business Ethics, 151, 279-293. https://doi.org/10.1007/s10551-016-3252-1.

Hibbert, S. A., Hogg, G., \& Quinn, T. (2005). Social entrepreneurship: Understanding consumer motives for buying The Big Issue. Journal of Consumer Behaviour, 4(3), 159-172.

Hill, T. E. (1971). Kant on imperfect duty and supererogation. Kant-Studien, 62, 55-76. https://doi.org/10.1515/ kant.1971.62.1-4.55.

Hockerts, K. (2006). Entrepreneurial opportunity in social purpose business ventures. In J. Mair, J. A. Robinson, \& K. Hockerts (Eds.), Social entrepreneurship (pp. 142-154). Basingstoke: Palgrave Macmillan.

Huehn, M. P. (2008). Unenlightened economism: The antecedents of bad corporate governance and ethical decline. Journal of Business Ethics, 81, 823-835. https://doi.org/10.1007/s1055 1-007-9550-x. 
Hühn, M. P. (2014). You reap what you sow: How MBA programs undermine ethics. Journal of Business Ethics, 121, 527-541. https://doi.org/10.1007/s10551-013-1733-z.

Kant, I. (1785/2012). Groundwork of the metaphysics of morals. Cambridge: Cambridge University Press.

Kinderman, D. (2012). 'Free us up so we can be responsible!' The coevolution of Corporate Social Responsibility and neo-liberalism in the UK, 1977-2010. Socio-Economic Review, 10, 29-57. https ://doi.org/10.1093/ser/mwr028.

Lasprogata, G. A., \& Cotten, M. N. (2003). Contemplating "Enterprise": The business and legal challenges of social entrepreneurship. American Business Law Journal, 41(1), 67-113.

Lehner, O. M., \& Kansikas, J. (2013). Pre-paradigmatic status of social entrepreneurship research: A systematic literature review. Journal of Social Entrepreneurship, 4(2), 1-23.

Light, P. C. (2006). Reshaping social entrepreneurship. Stanford Social Innovation Review, 4(3), 47-51.

Longino, H. (2008). Values, heuristics and the politics of knowledge. In M. Carrier, D. Howard, \& J. A. Kourany (Eds.), The challenge of the social and the pressure of practice: Science and values revisited (pp. 68-86). Pittsburgh, PA: University of Pittsburgh Press.

Mair, J., \& Martí, I. (2006). Social entrepreneurship research: A source of explanation, prediction, and delight. Journal of World Business, 41(1), 36-44.

Martí, I. (2018). Transformational business models, grand challenges, and social impact. Journal of Business Ethics, 152, 965-976. https://doi.org/10.1007/s10551-018-3824-3.

Martin, R. L., \& Osberg, S. (2007). Social entrepreneurship: The case for definition. Stanford Social Innovation Review, 5(2), 28-39.

Mayr, S. (2013). Neue Vorwürfe - Protokolle aus der Amazon-Galeere: "Als würden die Menschen dressiert werden". Süddeutsche Zeitung. Retrieved September 12, 2015, from https://www.suedd eutsche.de/bayern/neue-vorwuerfe-gegen-amazon-als-wuerdendie-menschen-dressiert-werden-1.1614066.

Molecke, G., \& Pinkse, J. (2017). Accountability for social impact: A bricolage perspective on impact measurement in social enterprises. Journal of Business Venturing, 32, 550-568. https://doi. org/10.1016/j.jbusvent.2017.05.003.

Myrdal, G. (2013). The political element in the development of economic theory: A collection of essays on methodology. Hoboken: Taylor and Francis.

Nicholls, A. (2008). Introduction. In A. Nicholls (Ed.), Social entrepreneurship: New models of sustainable social change (pp. 1-36). Oxford: Oxford University Press.

Nicholls, A. (2010). The legitimacy of social entrepreneurship: Reflexive isomorphism in a pre-paradigmatic field. Entrepreneurship Theory and Practice, 34(4), 611-633.

Nicolini, D. (2012). Practice theory, work, \& organization: An introduction. Oxford: Oxford University Press.

Ohreen, D. E., \& Petry, R. A. (2012). Imperfect duties and corporate philanthropy: A kantian approach. Journal of Business Ethics, 106, 367-381. https://doi.org/10.1007/s10551-011-1002-y.

One Acre Fund. (2019a). How we grow. Retrieved June 21, 2019, from https://oneacrefund.org/what-we-do/how-we-grow/.

One Acre Fund. (2019b). Program model. Retrieved June 21, 2019, from https://www.oneacrefund.org/our-approach/program-model

One Acre Fund. (2019c). Purpose and values. Retrieved June 21, 2019, from https://www.oneacrefund.org/about-us/purpose-values.

Peredo, A. M., \& Mclean, M. (2006). Social entrepreneurship: A critical review of the concept. Journal of World Business, 41(1), $56-65$.

Perrini, F., \& Vurro, C. (2006). Social entrepreneurship: innovation and social change across theory and practice. In J. Mair, J. A. Robinson, \& K. Hockerts (Eds.), Social entrepreneurship (pp. 57-85). Basingstoke: Palgrave Macmillan.
Pryor, C., Webb, J. W., Ireland, R. D., \& Ketchen, D. J., Jr. (2016). Toward an integration of the behavioral and cognitive influences on the entrepreneurship process. Strategic Entrepreneurship Journal, 10, 21-42. https://doi.org/10.1002/sej.1204.

Putnam, H. (2002). The collapse of the fact/value dichotomy and other essays. Cambridge, MA: Harvard University Press.

Robinson, R. (2019). The management nexus of imperfect duty: Kantian views of virtuous relations, reasoned discourse, and due diligence. Journal of Business Ethics, 157, 119-136. https://doi. org/10.1007/s10551-017-3671-7.

Rouse, J. (2001). Two concepts of practices. In T. R. Schatzki, K. Knorr-Cetina, \& E. V. Savigny (Eds.), The practice turn in contemporary theory (pp. 198-208). London: Routledge.

Rudner, R. (1953). The scientist qua scientist makes value judgments. Philosophy of Science, 20(1), 1-6.

Saebi, T., Foss, N. J., \& Linder, S. (2018). Social entrepreneurship research: Past achievements and future promises. Journal of Management, 45, 70-95. https://doi.org/10.1177/0149206318 793196.

Salzmann, O., Ionescu-somers, A., \& Steger, U. (2005). The business case for corporate sustainability: Literature review and research options. European Management Journal, 23, 27-36. https://doi. org/10.1016/j.emj.2004.12.007.

Santos, F. (2012). A positive theory of social entrepreneurship. Journal of Business Ethics, 111, 335-351. https://doi.org/10.1007/s1055 1-012-1413-4.

Schatzki, T. R. (2002). The site of the social: A philosophical account of the constitution of social life and change. University Park: Pennsylvania State University Press.

Seelos, C., \& Mair, J. (2005). Social entrepreneurship: Creating new business models to serve the poor. Business Horizons, 48, 241246. https://doi.org/10.1016/j.bushor.2004.11.006.

Selznick, P. (1992). The moral commonwealth: Social theory and the promise of community. Berkeley: University of California Press.

Sharir, M., \& Lerner, M. (2006). Gauging the success of social ventures initiated by individual social entrepreneurs. Journal of World Business, 41, 6-20. https://doi.org/10.1016/j.jwb.2005.09.004.

Shaw, E. (2004). Marketing in the social enterprise context: Is it entrepreneurial? Qualitative Market Research: An International Journal, 7, 194-205. https://doi.org/10.1108/13522750410540209.

Short, J. C., Moss, T. W., \& Lumpkin, G. T. (2009). Research in social entrepreneurship: Past contributions and future opportunities. Strategic Entrepreneurship Journal, 3, 161-194. https://doi. org/10.1002/sej.69.

Siqueira, A. C. O., Guenster, N., Vanacker, T., \& Crucke, S. (2018). A longitudinal comparison of capital structure between young for-profit social and commercial enterprises. Journal of Business Venturing, 33, 225-240. https://doi.org/10.1016/j.jbusv ent.2017.12.006.

Slottke, S. (2013). Social Entrepreneurship als multidimensionales Phänomen: Ansatzpunkte zur Theorieentwicklung aus der Perspektive Sozialer Arbeit. Baden-Baden: Nomos.

Thielemann, U. (1996). Das Prinzip Markt: Kritik der ökonomischen Tauschlogik (Vol. 15). Bern: Haupt.

Thielemann, U. (2000). A brief theory of the market - ethically focused. International Journal of Social Economics, 27(1), 6-31.

Thielemann, U. (2009). Der integrative Ansatz der Unternehmensethik: eine knappe Darstellung durch Abgrenzung vom ökonomistischen und vom separativen Konzept. In M. Maring (Ed.), Verantwortung in Technik und Ökonomie (pp. 207-217). Karlsruhe: Universitätsverlag Karlsruhe.

Thielemann, U. (2010). System Error: Warum der freie Markt zur Unfreiheit führt (Schriftenreihe / Bundeszentrale für Politische Bildung, Vol. 1052). Bonn: Bundeszentrale für Politische Bildung. 
Thielemann, U. (2010). Wettbewerb als Gerechtigkeitskonzept: Kritik des Neoliberalismus. Marburg: Metropolis.

Thielemann, U., \& Ulrich, P. (2009). Standards guter Unternehmensführung: Zwölf internationale Initiativen und ihr normativer Orientierungsgehalt. Bern: Haupt.

Thielemann, U., \& Wettstein, F. (2008). The case against the business case and the idea of "earned reputation": Discussion Papers of the Institute for Business Ethics No. 111, St. Gallen.

Thompson, J., \& Doherty, B. (2006). The diverse world of social enterprise: A collection of social enterprise stories. International Journal of Social Economics, 33(5/6), 361-375.

Thompson, J. L. (2002). The world of the social entrepreneur. International Journal of Public Sector Management, 15(4-5), 412-431.

Tracey, P., \& Jarvis, O. (2007). Toward a theory of social venture franchising. Entrepreneurship Theory and Practice, 31(5), 667-685.

Ulrich, P. (2008a). Integrative economic ethics: Foundations of a civilized market economy. Cambridge, NY: Cambridge University Press.

Ulrich, P. (2008b). Zivilgesellschaft: Dritter Sektor oder Dritter Weg?: Zur wirtschaftsethischen Bedeutung des Bürgerengagements. Korreferat zum Beitrag von Karl Gabriel. Zeitschrift für Wirtschafts- und Unternehmensethik, 9(3), 331-336.

Ulrich, P., \& Thielemann, U. (1993). How do managers think about market economies and morality? Empirical enquiries into business-ethical thinking patterns. Journal of Business Ethics, 12, 879-898. https://doi.org/10.1007/BF00871669.
Weber, M. (1978). Economy and society: An outline of interpretive sociology. New York: University of California Press.

Wicks, A. C. (1996). Overcoming the separation thesis. Business \& Society, 35, 89-118. https://doi.org/10.1177/000765039603500 108.

Young, D. R., \& Lecy, J. D. (2014). Defining the universe of social enterprise: Competing metaphors. VOLUNTAS: International Journal of Voluntary and Nonprofit Organizations, 25(5), $1307-1332$.

Yunus, M. (2010). Building social business: The new kind of capitalism that serves humanity's most pressing needs. New York: Public Affairs.

Yunus, M., Moingeon, B., \& Lehmann-Ortega, L. (2010). Building social business models: Lessons from the Grameen experience. Long Range Planning, 43, 308-325. https://doi.org/10.1016/j. lrp.2009.12.005.

Zahra, S. A., Gedajlovic, E., Neubaum, D. O., \& Shulman, J. M. (2009). A typology of social entrepreneurs: Motives, search processes and ethical challenges. Journal of Business Venturing, 24(5), 519-532.

Publisher's Note Springer Nature remains neutral with regard to jurisdictional claims in published maps and institutional affiliations. 